See discussions, stats, and author profiles for this publication at: https://www.researchgate.net/publication/273991895

\title{
Evaluation of Early and Late/Intermediate Maize Varieties for Grain Yield Potential and Adaptation to a Southern Guinea Savanna Agro-ecology of Nigeria
}

Article $\cdot$ March 2012

DOI: 10.5923/j.plant.20120202.03

CITATIONS

18

7 authors, including:

Bashir Omolaran Bello

Federal University Gashua, Yobe State, Nigeria

64 PUBLICATIONS 327 CITATIONS

SEE PROFILE

Musibau Adewuyi Azeez

Ladoke Akintola University of Technology

56 PUBLICATIONS 586 CITATIONS

SEE PROFILE

Some of the authors of this publication are also working on these related projects:
READS

966

A. Jimoh Mahamood

Lower Niger River Basin Development Authority, Ilorin 9 PUBLICATIONS 116 CITATIONS

SEE PROFILE

Project HUMAN IMPACT ON SOME ECONOMIC TREES OF OBA HILL FOREST RESERVE, OSUN STATE, NIGERIA View project

Project Green synthesis of metallic nanoparticles for novel biomedical applications View project 


\title{
Evaluation of Early and Late/Intermediate Maize Varieties for Grain Yield Potential and Adaptation to a Southern Guinea Savanna Agro-ecology of Nigeria
}

\author{
Bello O. B. ${ }^{1,{ }^{*}}$, Abdulmaliq S. Y. ${ }^{2}$, Ige S. A. ${ }^{3}$, Mahamood J. ${ }^{4}$, Oluleye F. ${ }^{5}$, Azeez M. A. ${ }^{6}$, Afolabi M. S. ${ }^{7}$ \\ ${ }^{1}$ Department of Biological Sciences, Fountain University, Osogbo, Osun State, Nigeria \\ ${ }^{2}$ Department of Agronomy, Ibrahim Badamasi Babangida University, Lapai, Niger State, Nigeria \\ ${ }^{3}$ Department of Agronomy, University of Ilorin, Ilorin, Nigeria \\ ${ }^{4}$ Lower Niger River Basin Development Authority, Ilorin, Kwara State, Nigeria \\ ${ }^{5}$ Kwara State University, Malete, Ilorin, Kwara State, Nigeria \\ ${ }^{6}$ Department of Plant Biology, Ladoke Akintola University of Technology, Ogbomoso, Nigeria \\ ${ }^{7}$ Department of Crop Science, Landmark University, Omuaran, Kwara State, Nigeria
}

\begin{abstract}
Drought-tolerant maize varieties belonging to two different maturity (10 early and 10 late/intermediate) groups were evaluated for yield and other related characters in the southern Guinea savanna (SGS) of Nigeria for two years (2009 and 2010). The differences among genotypes between and within maturity groups differed significantly $(\mathrm{P}<0.01)$ for grain yield, plant height, days to anthesis and silk. The effect of year $\mathrm{x}$ maturity group and year $\mathrm{x}$ maturity within group interactions was highly significant $(\mathrm{P}<0.01)$ only for grain yield. The rainfall patterns were favourable in both cropping years with comparable values of growth parameters. Late/intermediate maturing varieties (TZL COMP1-W C6 F2, SUWAN-1-SR-SYN, TZB-SR, OBA SUPER I, EV 8435-SR) out-yielded early maturing ones with yield advantage of 34.29\% and taller by $17.04 \%$ compared to early ones. However, early varieties were early to anthesis with $6.57 \%$ advantage over late/intermediate cultivars. Four early varieties (DMR-ESR Y CIF2, AC 90 POOL 16 DT, STR, TZE-W DT STR C4 and ACR 95TZE COMP4 C3) were superior for grain yield withn a range of 4.39 to $4.68 \mathrm{t} / \mathrm{ha}$. These genotypes could be used either as cultivar per se to escape the prolonged moisture stress during the later part of the cropping season or introgressed with favourable cultivars for high yield adaptable to drought-prone areas in the southern Guinea savanna agro-ecology.
\end{abstract}

Keywords Maize yield, early varieties, late/intermediate varieties, maturity group

\section{Introduction}

Maize (Zea mays L.) is an important staple food crop and provides bulk of raw materials for the livestock and many agro-allied industries in the world (Bello et al., 2010; Randjelovic et al., 2011).). The savanna agro-ecology of Nigeria has a great potential for food production because of its high solar radiation that favours maize production. In the southern guinea savannah (SGS) however, maize is grown twice due to bimodal rainfall pattern (a short early growing season followed by fairly long late season). Early maize varieties are usually planted at the onset of rainy season before it's fully established (March/April), and matured sooner than the traditional crops (sorghum [Sorghum bicolor (L.) Moench] and millet [Pennisetum glaucum (L.) R. Br.]). This succors in filling the hunger gap in July when all food

* Corresponding author:

obbello2002@yahoo.com (Bello, O. B.)

Published online at http://journal.sapub.org/plant

Copyright (C) 2012 Scientific \& Academic Publishing. All Rights Reserved reserves have been depleted after the long dry period in the zone. On the other hand, the late season crop is planted during the second cycle of rains (July/August). While the short early season is usually characterized by abrupt cessation of rains during crop cycle, the late season is normally affected by terminal drought.

The occurrence of extreme environmental events impose different degrees of drought stresses on crops thereby affecting growth duration, plant size, dry matter accumulations, assimilate reserves and partitioning to grains. As the episodes of water resources for agronomic uses become more limiting, the development of drought-tolerant (DT) lines becomes increasingly necessary. Drought occurring during or shortly before flowering in crops, the estimated yield loss may be in the range of 21 to $50 \%$ (Olaoye et al., 2009). The soil in the SGS is also fragile with low organic matter, poor buffering and water holding capacity, resulting in low nitrogen availability (Fakorede et al., 2001; 2003). Since the timing of mid-season drought is unpredictable, early maize cultivars that can tolerate the effects of reduced moisture supply during flowering could reduce farmers' risk in 
drought-affected ecologies (Olaoye et al., 2009; Hussain et al., 2011). Early maturing DT maize varieties are ideal for intercropping by providing less competition for moisture, light, and nutrients than late maturing ones. They also offer flexibility in planting dates, which enables: (i) multiple plantings in a season to spread risk of losing a single crop to drought (ii) late plantings during delayed onset of rainfall, and (iii) avoidance of known terminal drought periods during the cropping season (CIMMYT, 2000). occurring The occurrence of drought in most parts of West and Central Africa, has now made the production and utilization potential of DT maize varieties attract the attention of the national and international researchers to developi, testing and transferr high yielding and adapted maize cultivars to farmers (BaduApraku et al., 2003; Olaoye and Omueti 2006).

The release of improved drought-tolerant maize varieties by these research institutes has created assurance for increased maize productivity in the savanna agro-ecologies. These could not only be achieved by promoting rate of adoption of improved maize cultivars by the farmers, but also provide farmers opportunities to overcome the challenges to maize production, thereby improving food security in the West and Central Africa. From 1987 to date, the regional early and late/intermediate varietal trials have been organized by West and Central Africa Maize Collaborative Research Network (WECAMAN) and the Maize and Wheat Improvement Center (CIMMYT), Mexico as a vehicle for systematic testing and dissemination of elite maize across West African sub-region. They were on germplasm exchange among maize scientists in the sub-Sahara of West Africa with the aim of offering the opportunity to identify varieties suitable to their peculiar growing condition. Evaluation of extra early (80-85 days), early (90-95 days) and late/intermediate (100-105 days) maturing groups have formed part of their varietal trials in the marginal environments of the region under the auspices of International Institute of Tropical Agriculture (IITA) Ibadan, Nigeria (BaduApraku et al., 2003; Sallah et al., 2004; Olaoye and Omueti, 2006; Oluwaranti et al., 2008). Availability of the early and extra-early varieties is a strategy for adapting maize to the gradually shortening rainy season, so that maize could tolerate or/and escape the drought stress that occurs during the grain-filling stage in the late season. These cultivars are endowed with favourable genes for high yield (about 20$50 \%$ yield increase than other maize varieties) potential and stability across a broad range of water availability (Kucharik, 2008; Olaoye et al., 2009). On this evidence, assessment of early maturing DT varieties that fully explored the potential growing season and fit into the erratic rainfall pattern in the ecology is precondition to increasing maize yields. The present study was therefore conducted to evaluate the performance of early and late/intermediate DT maize maturity groups, with the view to identifying cultivars that are high yielding and adapted to marginal and drought-prone ecologies for farmers' use.

\section{Materials and Methods}

\section{Collection of planting materials}

The genetic materials used for this study was a set of drought-tolerant maize varieties belonging to two different maturity (10 early and 10 late/intermediate) groups. These varieties were developed by West and Central Africa Maize Collaborative Research Network (WECAMAN) which was originally part of the international trials coordinated by the IITA Ibadan, Nigeria. The popular local variety, AFO and Composite-Y were used as checks for both early and late/intermediate maturity groups respectively. The genotypes were evaluated for two years (2009 and 2010) during late growing seasons at the Lower Niger River Basin Development Authority station, Oke-Oyi, Ilorin, Nigeria (Latitude $8^{\circ} 30^{\prime} \mathrm{N}, 8^{\circ} 36^{\prime} \mathrm{E}$ and Longitude $4^{\circ} 31^{\prime} \mathrm{N}, 4^{\circ} 33^{\prime} \mathrm{E}$ ). Planting was carried out on $21^{\text {st }}$ July, 2009 and $27^{\text {th }}$ July, 2010 respectively.

\section{Soil analyses and rainfall data}

The physico-chemical characteristics of the soil at the experimental site were determined by collecting soil samples randomly at the depths of $0-15 \mathrm{~cm}$ and $15-30 \mathrm{~cm}$ respectively with an auger, and analyzed in the laboratory before planting in both cropping seasons (Table 1). The collected samples were air-dried and passed through $2 \mathrm{~mm}$ sieve to remove large particles, debris and stones. The sieved samples were analyzed for $\mathrm{pH}$ in 1:1 soil to water ratio using the Coleman's $\mathrm{pH}$ meter. Organic carbon was determined by Walkley and Black procedure (Nelson and Somers, 1992). Total nitrogen was determined by the micro Kjeldahl method (Bremner, 1965), while available phosphorus was extracted by Bray's $P_{1}$ method (Bray and Kurtz, 1945) and read from the atomic absorption spectrometer. Exchangeable $\mathrm{Ca}, \mathrm{Mg}$, $\mathrm{K}, \mathrm{Na}$ and effective cation exchangeable capacity (ECEC) were analyzed using Atomic Absorption Spectrophotometery (IITA, 1989), while textural analysis was by hydrometer method. Rainfall distribution data for 2009 and 2010 were also recorded (Figure 1).

Table 1. Physico-chemical characteristics of the soil in the experimental site prior to growing of maize at Ilorin, Nigeria in 2009 and 2010

\begin{tabular}{|c|c|c|c|c|}
\hline \multirow{2}{*}{ Soil properties } & \multicolumn{2}{|c|}{$0-15 \mathrm{~cm}$ depth } & \multicolumn{2}{|c|}{$15-30 \mathrm{~cm}$ depth } \\
\hline & 2009 & 2010 & 2009 & 2010 \\
\hline \multicolumn{5}{|l|}{ Physical characteristics } \\
\hline Sand $\%$ & 72.0 & 72.1 & 72.2 & 72.3 \\
\hline Clay \% & 6.0 & 6.3 & 6.3 & 6.4 \\
\hline Silt \% & 19.0 & 19.2 & 19.2 & 19.4 \\
\hline Texture & Sandy & Sandy & Sandy & Sandy \\
\hline 1exture & loam & loam & loam & loam \\
\hline \multicolumn{5}{|l|}{ Chemical characteristics } \\
\hline Soil PH (water) & 6.1 & 6.2 & 6.3 & 6.3 \\
\hline Exchangeable $\mathrm{Ca}^{2+}\left(\mathrm{Cmol} \mathrm{kg}^{-1}\right)$ & 1.5 & 1.5 & 1.6 & 1.5 \\
\hline Exchangeable $\mathrm{Mg}^{2+}\left(\mathrm{Cmol} \mathrm{kg}^{-1}\right)$ & 1.3 & 1.4 & 1.4 & 1.3 \\
\hline Exchangeable $\mathrm{Na}^{+}\left(\mathrm{Cmol} \mathrm{kg}^{-1}\right)$ & 0.18 & 0.18 & 0.18 & 0.18 \\
\hline Exchangeable $\mathrm{K}^{+}\left(\mathrm{Cmol} \mathrm{kg}^{-1}\right)$ & 0.29 & 0.30 & 0.29 & 0.30 \\
\hline Total acidity $\mathrm{H}^{+}\left(\mathrm{Cmol} \mathrm{kg}^{-1}\right)$ & 1.1 & 1.1 & 1.1 & 1.1 \\
\hline $\begin{array}{l}\text { Cation exchange capacity } \\
\left(\mathrm{Cmol} 1 \mathrm{~kg}^{-1}\right)\end{array}$ & 11.9 & 11.9 & 12.01 & 12.02 \\
\hline Organic Carbon \% & 8.7 & 8.8 & 8.6 & 8.6 \\
\hline Total Nitrogen $\%$ & 0.5 & 0.5 & 0.5 & 0.5 \\
\hline Available Phosphorus (mg kg $\left.{ }^{-1}\right)$ & 6.3 & 6.2 & 6.2 & 6.2 \\
\hline
\end{tabular}




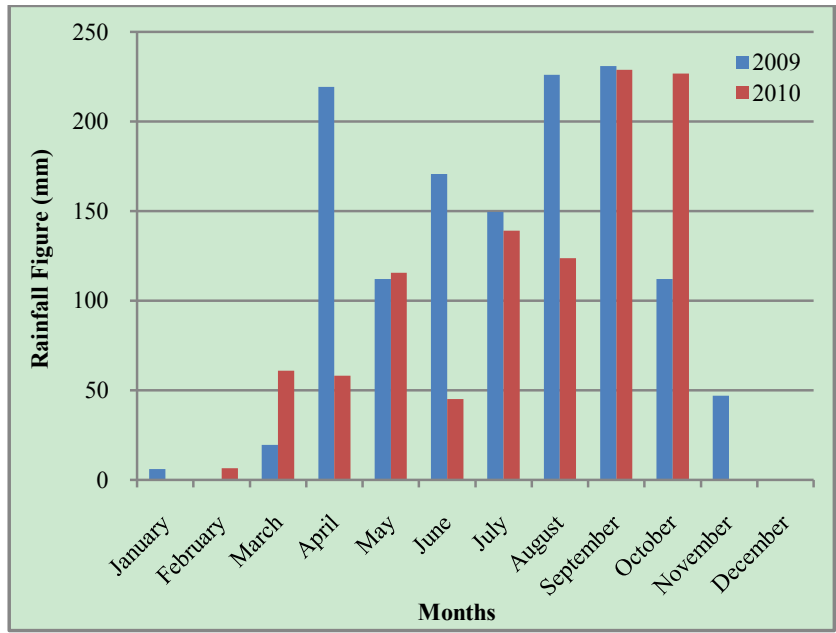

Source: Lower Niger River Basin Development Authority, Ilorin, Nigeria Figure 1. Monthly rainfall distribution pattern for Ilorin in 2009 and 2010

\section{Experimental layout and cultural practices}

Maize seeds (20 varieties) were planted on $29^{\text {th }}$ July, 2009 and $28^{\text {th }}$ July, 2010 in a randomized complete block design with four replications. The materials were planted in 4-row plots, $5 \mathrm{~m}$ long, with $0.75 \mathrm{~m}$ spacing between rows and $0.5 \mathrm{~m}$ spacing between plants. Within a row, three to four seeds were planted in a hill and later thinned to two plants after emergence to attain a population density of 53,333 plants $\mathrm{ha}^{-1}$. A compound fertilizer (NPK 15:15:15) was applied at the rate of $60 \mathrm{~kg} \mathrm{~N}, 60 \mathrm{~kg} \mathrm{P}$ and $60 \mathrm{~kg} \mathrm{~K} \mathrm{ha}^{-1}$ at three weeks after planting (WAP). An additional $60 \mathrm{~kg} \mathrm{~N}^{-1}{ }^{-1}$ was applied as top dressing at seven WAP using urea $(46 \% \mathrm{~N})$. Weed control was done chemically by the use of 5 litres per hectare pre-emergence herbicides (a.i. $3 \mathrm{~kg} / 1$ Metolachlor and $170 \mathrm{~g} / 1$ Atrazine). Hand weeding was also supplemented at four WAP prior to topdressing.

\section{Data collection}

Data were collected from the two middle rows in each plot. The parameters measured included: Days to anthesis and silking recorded as the number of days from planting to when $50 \%$ of the plants in each plot shed pollen and silks had emerged respectively. Anthesis-silking interval was computed as the difference between dates of silking and pollen shed. Plant and ear heights were measured as the distance $(\mathrm{cm})$ from the base of the plant to the height of the first tassel branch and the node bearing upper ear respectively. Plant aspect was rated visually on a scale of 1 to 5 where $1=$ excellent overall phenotypic appeal and $5=$ poor overall phenotypic appeal of plants. Ear aspect was also rated on a scale of 1 to 5 where 1 = clean, uniform, large and well-filled ears and $5=$ variable, small and partially filled cobs. The total number of plants and ears were counted in each plot at the time of harvest. The number of ears per plant was then calculated as the proportion of the total number of ears harvested divided by the total number of plants in a plot. All ears harvested from each plot were shelled to determine percentage moisture at harvest. Grain yield was adjusted to $12.5 \%$ moisture and used to compute grain yield in tonnes per hectare $(\mathrm{t} / \mathrm{ha})$.

\section{Data analyses}

Data collected in respect of each maturity group were first computed with analysis of variance (ANOVA) separately before a combined ANOVA across maturity groups and the two years growing seasons using PROC GLM model of SAS (SAS Institute, 2007) to compute mean squares for each character. The degree of variation was determined using $\%$ coefficient of variation $\mathrm{P}<0.05$. Differences in character means were also measured using Least Significant Difference (LSD).

\section{Results}

\section{Distribution of rainfall and soil analysis}

In the cropping seasons of 2009 and 2010, there were false start of rain from February to March and a break in July, 2010. This then followed by adequate and evenly distribution throughout the flowering/grain filling periods of July to October. In each of the growing year, there was a significant rainfall drop (August break) in August, 2010 and October 2009. (Figure 1). However, the physico-chemical analysis of $0-15$ and $15-30 \mathrm{~cm}$ soil depth showed that the soil at the experimental area was comparable in both depths in both years (Table 1). The particle size analysis of the soil type was sandy loam with a high proportion of sand $(72.2 \%)$ but less clay $(6.3 \%)$, silt $(19.2 \%)$. On the chemical characteristics, the soil was slightly acidic ( $\mathrm{pH}$ of 6.2 ) with adequate cation exchange capacity $\left(11.90 \mathrm{Cmol} \mathrm{kg}^{-1}\right)$. Although the total nitrogen $(0.5 \%)$, organic carbon $(8.7 \%)$, calcium $(1.5 \mathrm{Cmol}$ $\left.\mathrm{kg}^{-1}\right)$ and magnesium $\left(1.3 \mathrm{Cmol} \mathrm{kg}^{-1}\right)$ values were low, there was a high concentration of available phosphorus $(6.2 \mathrm{Cmol}$ $\left.\mathrm{kg}^{-1}\right)$.

\section{Mean squares from combined analysis of variance}

The differences among genotypes between and within maturity groups differed significantly $(\mathrm{P}<0.01)$ for grain yield, plant height, days to anthesis and silk (Table 2). The effect of year $\mathrm{x}$ maturity group and year $\mathrm{x}$ maturity within group interactions were highly significant $(\mathrm{P}<0.01)$ only for grain yield. The sources of variation however were nonsignificant for all the characters in both years. The rainfall patterns were favourable in both cropping years (Figure 1) with comparable values of growth parameters.

\section{Genotypic performance for yield and other agronomic characters}

Ranges in the means for grain yield, ears per plant, anthesis-silking interval (ASI), plant and ear aspect scores were lower in the late/intermediate maturity genotypes than early varieties (Table 3). While ranges in the means for ear height, days to anthesis and silk were high, reverse was the case for the values of plant height with comparable results. Although, early varieties were early to anthesis with $6.57 \%$ advantage over late/intermediate cultivars, late/intermediate varieties had grain yield advantage of $34.29 \%$ and taller by $17.04 \%$ compared to early varieties regardless of the growing year. Among early varietal group, DMR-ESR Y CIF2 was superior with highest grain yield followed by AC 90 POOL 
16 DT STR, TZE-W DT STR C4 and ACR 95TZE COMP4 $\mathrm{C} 3$ in that order. However, most of the late/intermediate maturing varieties out-yielded early maturing ones. In late/intermediate maturing group, TZL COMP1-W C6 F2, SUWAN-1-SR-SYN, TZB-SR, OBA SUPER I, EV 8435SR yielded higher with yield advantage of $29.06 \%$ compared with the best (DMR-ESR Y CIF2) in the early group. It is noteworthy that the two local varieties as checks (SUWAN-1-SR and AFO) were the poorest for grain yield. On the other hand, similar and moderate ASI, ears per plant as well as plant and ear aspects scores were recorded between and within maturity groups.

Among early maturity group, ranking based on grain yield and days to silk showed that DMR-ESR Y CIF2 ranked top followed by AC 90 POOL 16 DT STR (Table 4). Consequently, ACR 95TZE COMP4 C3 and Syn E2 that had top entry for grain yield, ranked a distant $10^{\text {th }}$ because of lateness in anthesis. Check variety (AFO) that was the poorest for grain yield had rank entry of $6^{\text {th }}$ based on its earliness to anthesis. However, among late/intermediate maturity groups, SUWAN-1-SR-SYN ranked top followed by TZB-SR., TZL COMP1-W C6 F2 and OBA SUPER I in that order (Table 5). Check variety, SUWAN-1-SR that was the poorest for grain yield also ranked a distant $10^{\text {th }}$ based on its lateness to anthesis. It is important to note that the local variety, SUWAN-1-SR that was the lowest grain yielding had yield advantage of $129 \%$ after being improved to form SUWAN-1-SR-SYN.

Table 2. Mean squares from combined ANOVA for grain yield and other related characters in early and late/intermediate maize maturity groups

\begin{tabular}{lllllllllll}
\hline Sources of variation & Df & $\begin{array}{l}\text { Days to } \\
\text { anthesis }\end{array}$ & $\begin{array}{l}\text { Days to } \\
\text { silking }\end{array}$ & $\begin{array}{l}\text { ASI } \\
\text { (days) }\end{array}$ & $\begin{array}{l}\text { Plant } \\
\text { height }(\mathrm{cm})\end{array}$ & $\begin{array}{l}\text { Ear } \\
\text { height }(\mathrm{cm})\end{array}$ & $\begin{array}{l}\text { Plant } \\
\text { aspect }\end{array}$ & $\begin{array}{l}\text { Ear } \\
\text { aspect }\end{array}$ & $\begin{array}{l}\text { Ears } \\
\text { per plant }\end{array}$ & $\begin{array}{l}\text { Grain } \\
\text { yield (t/ha) }\end{array}$ \\
\hline Year (y) & 1 & 4.45 & 3.29 & 6.34 & 8.18 & 13.07 & 34.21 & 12.45 & 23.19 & 1.23 \\
Rep (Year) & 6 & 20.43 & 11.37 & 0.45 & 34.56 & 9.38 & 0.38 & 7.36 & 31.75 & 15.92 \\
Maturity group (G) & 1 & $987.25^{* *}$ & $1243.36^{* *}$ & 12.56 & $897.45^{* *}$ & 34.42 & 13.78 & 10.04 & 15.11 & $1342.74^{* *}$ \\
Variety/group (V/G) & 19 & $1265.34^{* *}$ & $952.14^{* *}$ & 13.24 & $875.24 * *$ & 23.45 & 24.01 & 15.19 & 13.44 & $945.23^{* *}$ \\
Y x G & 9 & 1.96 & 24.16 & 32,18 & 54.33 & 13.76 & 23.61 & 1.93 & 24,61 & $1528.22^{* *}$ \\
Y x V/G & 9 & 10.75 & 24.89 & 3.65 & 17.34 & 54.29 & 28.63 & 41.39 & 31.72 & $987.12^{* *}$ \\
Error & 181 & 13.26 & 5.36 & 10.38 & 1.83 & 32.49 & 28.26 & 36.81 & 21.59 & 1.58 \\
\hline
\end{tabular}

***, significant at $\mathrm{P}<0.05$ and $\mathrm{P}<0.01$ respectively

Table 3. Mean grain yields and other related characters for early and late/intermediate maize maturity groups at Ilorin, Nigeria in 2009 and 2010

\begin{tabular}{|c|c|c|c|c|c|c|c|c|c|}
\hline Early maturing group & $\begin{array}{l}\text { Days to } \\
\text { anthesis }\end{array}$ & $\begin{array}{l}\text { Days to } \\
\text { silking }\end{array}$ & ASI & $\begin{array}{l}\text { Plant } \\
\text { height }(\mathrm{cm})\end{array}$ & $\begin{array}{l}\text { Ear } \\
\text { height }(\mathrm{cm})\end{array}$ & $\begin{array}{l}\text { Plant } \\
\text { aspect }\end{array}$ & $\begin{array}{l}\text { Ear } \\
\text { aspect }\end{array}$ & $\begin{array}{l}\text { Ears per } \\
\text { plant }\end{array}$ & $\begin{array}{l}\text { Grain } \\
\text { yield }(\mathrm{t} / \mathrm{ha})\end{array}$ \\
\hline EV DT-Y 2000 STR C0 & 59.4 & 62.5 & 3.1 & 132.4 & 58.5 & 2.34 & 2.13 & 0.97 & 3.23 \\
\hline EV DT-W 97 STR C1 & 55.2 & 56.5 & 2.8 & 127.5 & 57.7 & 2.03 & 2.92 & 0.94 & 3.17 \\
\hline EV DT-Y 2000 STR QPM C0 & 59.5 & 62.4 & 2.9 & 128.2 & 60.4 & 2.70 & 2.74 & 0.84 & 2.34 \\
\hline DMR-ESR Y CIF2 & 56.7 & 58.8 & 2.6 & 138.8 & 61.7 & 2.86 & 2.02 & 0.73 & 4.68 \\
\hline BG 97 TZE COMP 3 × 4 & 60.1 & 62.9 & 2.8 & 127.6 & 51.9 & 2.12 & 2.73 & 0.83 & 2.62 \\
\hline TZE-WＤT STR C4 & 60.6 & 62.3 & 2.7 & 137.4 & 62.5 & 2.93 & 2.88 & 0.85 & 4.44 \\
\hline TZE-W DT STR QPM C0 & 61.5 & 63.7 & 2.7 & 129.9 & 56.8 & 2.75 & 2.06 & 0.92 & 3.60 \\
\hline AC 90 POOL 16 DT STR & 58.2 & 60.5 & 2.8 & 140.0 & 62.4 & 2.56 & 2.87 & 0.86 & 4.60 \\
\hline ACR 95TZE COMP4 C3 & 58.8 & 60.7 & 2.9 & 130.4 & 58.7 & 2.78 & 2.14 & 0.91 & 4.39 \\
\hline TZE COMP 3 DT C3 & 54.3 & 57.0 & 2.7 & 124.7 & 56.3 & 2.04 & 2.94 & 0.96 & 3.57 \\
\hline AFO (LOCAL CHECK) & 54.5 & 56.6 & 2.7 & 118.1 & 51.5 & 2.59 & 2.77 & 0.99 & 2.17 \\
\hline Mean & 58.1 & 60.4 & 2.8 & 130.5 & 58.0 & 2.5 & 2.6 & 0.9 & 3.50 \\
\hline Range & 7.2 & 7.2 & 1.8 & 21.9 & 11 & 0.9 & 0.92 & 0.26 & 2.51 \\
\hline SE & 3.54 & 23.12 & 4.75 & 11.52 & 14.39 & 1.09 & 3.81 & 12.93 & 13.52 \\
\hline $\operatorname{LSD}(0.05)$ & $2.13 * *$ & $1.23 *$ & ns & $4.17 * *$ & ns & ns & ns & ns & $1.21 * *$ \\
\hline $\mathrm{CV}(\%)$ & 4.14 & 9.27 & 13.17 & 28.33 & 13.71 & 12.64 & 2.34 & 14.19 & 12.24 \\
\hline \multicolumn{10}{|l|}{$\begin{array}{l}\text { Late/ intermediate maturing } \\
\text { group }\end{array}$} \\
\hline DT-SR-W C0 F2 & 65.5 & 67.6 & 2.0 & 168.6 & 69.6 & 2.35 & 2.12 & 0.99 & 4.88 \\
\hline DT-SYN-1-W & 67.6 & 69.4 & 2.8 & 175.7 & 72.7 & 2.13 & 2.93 & 0.85 & 4.22 \\
\hline TZL COMP1-W C6 F2 & 67.3 & 69.5 & 3.1 & 178.3 & 70.4 & 2.70 & 2.75 & 0.90 & 5.94 \\
\hline IWD C2 SYN F2 & 69.6 & 72.2 & 2.6 & 153.7 & 60.2 & 2.84 & 2.57 & 0.94 & 2.96 \\
\hline SUWAN-1-SR-SYN & 58.8 & 60.7 & 2.9 & 179.4 & 80.7 & 2.73 & 2.15 & 0.97 & 6.41 \\
\hline White DT STR SYN & 69.2 & 71.5 & 2.8 & 167.9 & 70.5 & 2.89 & 2.13 & 0.91 & 3.22 \\
\hline TZUTSY-WSGY-SYN & 69.1 & 71.3 & 2.7 & 170.6 & 70.8 & 2.16 & 2.99 & 0.86 & 3.87 \\
\hline TZB-SR & 63.4 & 64.7 & 2.8 & 176.3 & 72.3 & 2.74 & 2.74 & 0.83 & 5.95 \\
\hline OBA SUPER I & 63.3 & 65.2 & 2.9 & 175.5 & 81.5 & 2.34 & 2.42 & 0.89 & 5.84 \\
\hline EV 8435-SR & 69.6 & 71.9 & 2.8 & 180.5 & 70.3 & 2.03 & 2.86 & 0.84 & 5.24 \\
\hline SUWAN-1-SR (LOCAL CHECK) & 69.9 & 71.8 & 2.9 & 158.7 & 59.5 & 2.70 & 2.73 & 0.80 & 2.80 \\
\hline Mean & 66.7 & 68.7 & 2.8 & 171.4 & 70.8 & 2.5 & 2.6 & 0.9 & 4.70 \\
\hline Range & 11.1 & 11.5 & 1.3 & 21.8 & 22.0 & 0.86 & 0.87 & 0.19 & 2.44 \\
\hline SE & 1.13 & 1.26 & 0.70 & 14.30 & 9.01 & 0.61 & 0.31 & 0.08 & 1.28 \\
\hline $\operatorname{LSD}(0.05)$ & $1.45^{* *}$ & $2.87 * *$ & ns & $3.24 * *$ & ns & ns & ns & ns & $1.37 * *$ \\
\hline CV (\%) & 1.05 & 13.5 & 0.36 & 2.83 & 5.87 & 13.41 & 3.09 & 11.75 & 13.56 \\
\hline + Differential & 12.9 & 12.1 & -15 & 23.9 & 17.5 & 0 & 0 & 0 & 39.6 \\
\hline
\end{tabular}

$*$, **; Significant F-Test at $\mathrm{p}<0.05$ and $\mathrm{p}<0.001$ levels, respectively; +Difference between early and late/intermediate maize maturity groups expressed as $\%$ of former. ASI = Anthesis-silking interval 
Table 4. Ranking of entries within each maturity group based on days to silk and grain yield

\begin{tabular}{|c|c|c|c|c|c|c|c|}
\hline & \multicolumn{3}{|c|}{ Ear maturity group } & & \multicolumn{3}{|c|}{ Late/intermediate maturity group } \\
\hline & $\begin{array}{l}\text { Grain } \\
\text { yield }\end{array}$ & $\begin{array}{l}\text { Days to } \\
\text { silking }\end{array}$ & $\begin{array}{l}\text { Total } \\
\text { ranking }\end{array}$ & & $\begin{array}{l}\text { Grain } \\
\text { yield }\end{array}$ & $\begin{array}{l}\text { Days to } \\
\text { silking }\end{array}$ & $\begin{array}{l}\text { Total } \\
\text { ranking }\end{array}$ \\
\hline EV DT-Y 2000 STR C0 & 7 & 9 & 16 & DT-SR-W C0 F2 & 6 & 4 & 10 \\
\hline EV DT-W 97 STR C1 & 8 & 1 & 9 & DT-SYN-1-W & 7 & 5 & 12 \\
\hline EV DT-Y 2000 STR QPM C0 & 10 & 8 & 18 & TZL COMP1-W C6 F2 & 3 & 6 & 9 \\
\hline DMR-ESR Y CIF2 & 1 & 4 & 5 & IWD C2 SYN F2 & 10 & 11 & 21 \\
\hline BG 97 TZE COMP $3 \times 4$ & 9 & 10 & 19 & SUWAN-1-SR-SYN & 1 & 1 & 2 \\
\hline TZE-W DT STR C4 & 3 & 7 & 10 & White DT STR SYN & 9 & 8 & 17 \\
\hline TZE-W DT STR QPM C0 & 5 & 11 & 16 & TZUTSY-WSGY-SYN & 8 & 7 & 15 \\
\hline AC 90 POOL 16 DT STR & 2 & 5 & 7 & TZB-SR & 2 & 2 & 4 \\
\hline ACR 95TZE COMP4 C3 & 4 & 6 & 10 & OBA SUPER I & 4 & 3 & 7 \\
\hline TZE COMP 3 DT C3 & 6 & 3 & 8 & EV $8435-S R$ & 5 & 10 & 15 \\
\hline AFO (LOCAL CHECK) & 11 & 2 & 13 & SUWAN-1-SR (LOCAL CHECK) & 11 & 9 & 20 \\
\hline
\end{tabular}

Table 5 Correlations between traits in early and late/intermediate maize maturity groups at Ilorin, Nigeria in 2009 and 2010

\begin{tabular}{|c|c|c|c|c|c|c|c|c|c|}
\hline $\begin{array}{l}\text { Early and late/ intermediate } \\
\text { maturity groups }\end{array}$ & $\begin{array}{l}\text { Days to } \\
\text { anthesis }\end{array}$ & $\begin{array}{l}\text { Days to } \\
\text { silking }\end{array}$ & $\begin{array}{l}\text { ASI } \\
\text { (days) }\end{array}$ & $\begin{array}{l}\text { Plant height } \\
(\mathrm{cm})\end{array}$ & $\begin{array}{l}\text { Ear height } \\
(\mathrm{cm})\end{array}$ & $\begin{array}{l}\text { Plant } \\
\text { aspect }\end{array}$ & $\begin{array}{l}\text { Ear } \\
\text { aspect }\end{array}$ & $\begin{array}{l}\text { Ears per } \\
\text { plant }\end{array}$ & $\begin{array}{l}\text { Grain yield } \\
(\mathrm{t} / \mathrm{ha})\end{array}$ \\
\hline Days to anthesis & & $0.97^{* *}$ & 0.18 & 0.36 & -0.14 & -0.42 & -0.14 & -0.45 & $0.57 *$ \\
\hline Days to silk & & & 0.07 & 0.16 & 0.34 & -0.67 & -0.34 & -0.09 & 0.34 \\
\hline ASI (days) & & & & -0.43 & -0.59 & -0.16 & -0.34 & $-0.69 *$ & 0.45 \\
\hline Plant height & & & & & -0.11 & $-0.79 * *$ & $0.75 * *$ & 0.45 & $0.67 *$ \\
\hline Ear height & & & & & & -0.56 & -0.23 & 0.14 & $0.61 *$ \\
\hline Plant aspect & & & & & & & $0.79 * *$ & -0.12 & 0.05 \\
\hline Ear aspect & & & & & & & & -0.37 & 0.12 \\
\hline Ears per plant & & & & & & & & & 0.25 \\
\hline Grain yield (t/ha) & & & & & & & & & \\
\hline
\end{tabular}

\section{Correlation among traits in early and late/intermediate maize varieties}

Grain yield showed positive and significant association with day to anthesis, plant and ear heights, but positive and non-significant for days to silking, ASI, ears per plant, plant and ear aspects (Table 5). Days to anthesis was positive and significantly $(\mathrm{P}<0.05)$ associated with days to silking, but positive and non-significantly correlated with ASI and plant height, as well as negative and non-significant associated with ear height as well as plant and ear aspects. Plant height however was negative and significantly correlated with plant aspect, but positive and significantly associated with ear aspect, as well as positive and non-significantly correlated to ears per plant.

\section{Discussion}

Precipitation pattern of rainfall has great impact in the expression of plants' potentials during period of flowering/ grain filling of the crop growth cycle, especially maize. It also plays significant role in stimulating plants to speed up the process of maturation. Rainfall distribution and amount was probably the single most important environmental factor that affected overall crop performance in this study. The rainfall patterns were favourable in both cropping years which resulted to comparable values of the agronomic parameters (Figure. 1). For example, soil moisture that was not limiting at anthesis during the two growing years created favourable environments for seed set and translocation of assimilates to grain filling. Though, soil analysis of the ex- perimental site was sandy loam and slightly acidic favourable for maize growth, the soil nutrients especially nitrogen and organic matter were low. This may be due to continuous cropping of the land over four years without fallowing. With the appreciable application of fertilizer, appropriate weeding and favourable rainfall probably gave individual genotype ample opportunity to express their yield potentials. On the other hand, the differences in performance of the genotypes both between and within each maturity groups for grain yield, plant height, days to anthesis and silking confirmed the diversity of the genotypes and their differences for these characters. Year $\mathrm{x}$ maturity and year $\mathrm{x}$ maturity within group interactions that were significant only for grain yield underscored the differences in genetic makeup of the genotypes which have pre-requisite advantages in breeding for improved grain yield. Furthermore, this wide variability observed for these yield parameters showed that they were quantitatively inherited and offered way for further improvement through selection (Bello and Olaoye, 2009). These results were expected as the varieties were of different maturity classes (early and late/intermediate maturity), different genetic backgrounds and bred for different traits such as drought tolerance, downy mildew resistance and streak resistance (Oluwaranti et al., 2008).

Plant height is not only important for breeding of new varieties of maize, for green and dry matter production, but also for grain yield. The present result revealed highly significant variability in both early and late/intermediate varieties for plant height (Table 2). Plant height has been observed to be controlled by the expression of many genes and the interactions between these genes (Yamakawa et al., 2006; 
Tahir et al., 2008). Many researchers have shown highly significant variability in plant height in various maize genotypes (Salami et al., 2007; Naushad et al., 2007; Nazir et al., 2010; Iqbal et al., 2010a; Iqbal et al., 2010b). High correlation of grain yield with plant height was earlier reported by other researchers (Bello et al., 2010; Nazir et al., 2010). Nazir et al., (2010) also reported that plant height was positively correlated with days to flowering morphologically, as internodes' formation stops at floral initiation, and that early flowering maize varieties are usually shorter in height.

Ear height has also been described to be one of the most important selection criteria in most breeding programmes especially the root and stock lodging (Esechie et al., 2004).. High ear position could be susceptible to root and stock lodging, therefore the plant breeders usually prefer selecting for lower ear position in maize (Esechie et al., 2004; Salami et al., 2007). Early varieties were shorter compared to late/intermediate with high ear heights in this study. Some early varieties (DMR-ESR Y CIF2, AC 90 POOL 16 DT STR, TZE-W DT STR C4 and ACR 95TZE COMP4 C3) that had short ear height were high yielding. Previous researcher reported reduced ear height and increased grain yield in maize (Olakojo and Olaoye, 2005; Salami et al., 2007; Nazir et al., 2010). Lower plant and ear height augments plant lodging resistance in maize with increase grain yield (Esechie et al., 2004). While high vertical root-pulling resistance (lodging resistance) took up more $\mathrm{N}$ and utilized it more efficiently, better agronomic performance and higher yield resulted (Kamara et al., 2003; Liu and Wiatrak, 2011). Therefore, these early varieties could also be $\mathrm{N}$-efficient or tolerant to $\mathrm{N}$ deficiency. Consequently, low ear heights could be suited to the conditions of small-holder farmers because the farmers hire small children and women for harvest. Harvesting using children becomes less cumbersome, and losses due to "gleaning" are reduced. Accessibility of short and early maturing varieties to small-holder farmers has a good advantage, because higher yields could result from small cultivated area with increase in plant density (Nik et al., 2011). Furthermore, shorter plants attached with less and short leaves require high plant density, and could compete for light and soil nutrients for high yield favorably than the taller ones. For large-scale commercial farmers utilizing combined harvester, the operation is also less tedious. With the lodging resistance, large-scale farmer does not need to recruit extra hands to pick ears from lodged plants. (Ahmad et al., 2011). also reported that availability of earlier maize varieties with shorter plant height, lower leaf number, upright leaves, smaller tassels and better synchrony between male and female flowering time, has enhanced the ability of maize to face high plant populations without showing excessive barrenness.

Consistent number of days (3 days) was recorded for anthesis-silking interval (ASI) among early and late/ intermediate maturity groups in both years. This indicated an interval of 3 days between pollen shed and silk intrusion in the genotypes. Bello and Olaoye (2009) described ASI as a measure of nicking (synchronization) of pollen shed with silking. ASI has been reported to be a valuable diagnostic trait for cultivar performance under stress than days to silking per se, since it is largely independent of maturity differences among cultivars (Ibikunle et al., 2009; Abdalla et al., 2010). The number of ears per plant decreased significantly as ASI increased, and this trait was a major factor that contributed to differences between the top and lowest yielding genotypes under drought stress ((Bello and Olaoye, 2009). Genotypes with reduced ASI will allow for better fertilization and good cob fill (Ibikunle et al., 2009; Ahmad 2011) Therefore, selection for reduced ASI in tropical maize varieties has been shown to be correlated with improved yields under drought stress (Ibikunle et al., 2009; Abdalla et al., 2010; Ahmad 2011). Plant and ear aspects are also vital in determining varietal acceptability under farmer's condition. Our result showed that among early and late/intermediate maturity groups, plant and ear aspects were fair in overall phenotypic appeal (2.6), but not significantly different in both years (Table 3 ). This indicated that these genotypes were not greatly affected with prevalent diseases during the two cropping seasons.

Comparison between the early and late/intermediate maturity showed that most of the late/intermediate varieties out yielded early varieties. Late/intermediate varieties were late to maturity, higher in plant and ear heights and yield, compared to early group. It is generally recognized that longer maturity variety produced greater yield to enable for a long duration in metabolic transformation into grain and stover yields (Agele, 2006; Golbashy et al., 2010; Song et al., 2010; Hussain et al., 2011; Wang et al., 2011). Early maturing varieties on the other hand, required fewer corn heat units to reach flowering, while late maturing cultivars exhibited extended vegetative period. Therefore, early flowering maize plants are smaller and have fewer leaves with low grain yield compared with late cultivars (Shi et al., 2008; Akbar et al. 2009; Kamara et al., 2009; Wang et al., 2010; Khan et al., 2011). However, grain yield and earliness to silk are two important characters that can be used in ranking genotypes for their suitability as cultivars especially in a drought-prone ecology such as savannas (Table 4). Earliness to anthesis and/ or silking allows short growth duration and maturity; and these could constitute important attributes of drought escape which often make earlier maturing maize genotypes adapt better to late season moisture stress than late maturing ones (Olakojo and Olaoye, 2005; Naushad et al., 2007; Salami et al., 2007; Akbar et al., 2008; Shi et al., 2008; Nazir et al., 2010; Majid et al., 2010). This therefore showed a direct relationship between grain yield and maturity irrespective of the group. Reports from WECAMAN regional trials (Anon, 2001) also indicated that this situation is not peculiar to this study. Therefore, four early varieties (DMR-ESR Y CIF2, AC 90 POOL 16 DT STR, TZE-W DT STR C4 and ACR 95TZE COMP4 C3) that combined low plant and ear heights and earliness to anthesis with grain yield were likely related to their earliness in reaching maturity which permitted the genotypes to better utilize the available soil moisture during anthesis (Olaoye et al., 2009). 
They probably contain certain attributes of drought escape and could adapt better to late season moisture stress than late maturing counterparts especially in the erratic rainfall pattern of the SGS agro-ecology (Shi et al., 2008; Wang et al., 2011). Nonetheless, AFO that was earliest to anthesis (54.5 days) among all the genotypes could be hybridized with higher yielding varieties for yield improvement in the sub-region. In conclusion, late/intermediate varieties (SUWAN-1-SR-SYN, TZB-SR., TZL COMP1-W C6 F2 and OBA SUPER I) which combined grain yield with earliness to silking and appreciable ASI and ear aspect among others could be grown in the zone. These superior varieties that flowered and matured earlier with high yield could be used to escape the prolonged moisture stress during the later part of the cropping season. They could be tested on the farmers' field for adaptation and adoption by the farmers. They could also serve as potential sources of unique combinations of favorable alleles for developing high yielding varieties adapted to drought affected areas in West and Central Africa.

\section{REFERENCES}

[1] Abdalla AE, Mahmoud FM and El Naim AM (2010). Evaluation of some maize (Zea mays L.) varieties in different environments of the Nuba mountain of Sudan. Austr. J. Basic and Applied Sci., 4(12): 6605-6610.

[2] Agele SO (2006). Weather and seasonal effects on growth, seed yield and soluble carbohydrate concentrations in selected maize cultivars in the humid areas of Nigeria. Afr. J. Agric. Res., 4(1): 101-110.

[3] Ahmad SQ, Khan S, Ghaffar M and Ahmad F (2011). Genetic diversity analysis for yield and other parameters in maize (Zea mays L.) genotypes. Asian J. Agric. Sci., 3(5): 385-388.

[4] Akbar M, Shakoor MS, Hussain A and Sarwar M (2008). Evaluation of maize 3-way crosses through genetic variability, broad sense heritability, characters association and path analysis. J. Agric. Res., 46(1): 39-45.

[5] Akbar M, Saleem M, Ashraf MY, Hussain A, Azhar FM and Ahmad R (2009). Combining ability studies for physiological and grain yield traits in maize at two temperatures. Pakistan J. Bot. 41(4): 1817-1829.

[6] Anon (2001). WECAMAN Regional uniform variety trials for 2000. Annual Report of West and Central Africa Maize Collaborative Research Network. 62 pp.

[7] Badu-Apraku B, Abamu FJ, Menkir A, Fakorede AB, Obeng-Antwi $\mathrm{K}$ and The $\mathrm{C}$ (2003). Genotype by environment interactions in the regional early maize varietal trials in West and Central Africa. Maydica 48: 93-104.

[8] Bello OB and Olaoye G (2009). Combining ability for maize grain yield and other agronomic characters in a typical southern guinea savanna ecology of Nigeria. Afr. J. Biotech., 8 (11): $2518-2522$.

[9] Bello OB, Abdulmaliq SY, Afolabi MS and Ige SA (2010). Correlation and path coefficient analysis of yield and agronomic characters among open pollinated maize varieties and their $F_{1}$ hybrids in a diallel cross. Afri. J. Biotech., 9 (18): 2633-2639.

[10] Bray RH and Kurtz LT (1945). Determination of total organic and available forms of phosphorus in soils. Soil Sci., Vol. 59, pp. 39-45.

[11] Bremner JM (1965). Total nitrogen. I methods of soil analysis. II chemical and microbiological properties. In: Black CA, Evans DD, White JL, Ensminger LE, Clerk FE and Dinauer RC (eds). Agronomy Monograph, 9, American Society of Agronomy Madison, Wisconson USA, pp. 26.

[12] CIMMYT (2000). CIMMYT-Zimbabwe: 2000 Research highlights. Harare, Zimbabwe.

[13] Esechie HA, Rodriguez V, Al-Asmi H (2004). Comparison of local and exotic maize varieties for stalk lodging components in a desert climate. Eur. J. Agron., 21(1): 21-30.

[14] Fakorede MAB, Fajemisin JM, Ladipo JL, Ajala SO and Kim SK (2001). Development and regional deployment of streak virus maize germplasm: an overview. Pp. 503-516 in Jacqueline d'A Hughes and Babajide O Odu (eds). Plant virology in Sub-Saharan Africa. Proc. of a conference organized by the International Institute of Tropical Agriculture, Ibadan $4^{\text {th }}-8^{\text {th }}$ June, 2001.

[15] Fakorede MAB, Badu-Apraku B, Kamara AY, Menkir A and Ajala SO (2003). Maize revolution in West and Central Africa: An overview. In: Badu-Apraku B, Fakorede MAB, Ouedraogo M, Carsky RJ and Menkir, A. (eds.). Maize revolution in West and Central Africa. Proceedings of a Regional Maize Workshop, 14 -18 May, 2001, IITA-Cotonou, Benin Republic, WECAMAN/IITA, pp. 3-5.

[16] Golbashy M, Ebrahimi M, Khorasani SKi, Choukan R (2010). Evaluation of drought tolerance of some corn (Zea mays L.) hybrids in Iran. Afr. J. Agric. Res., 5(19): 2714-2719.

[17] Hussain N, Khan MY and Baloch MS (2011). Screening of maize varieties for grain yield at Dera Ismail Khan. J. Animal and Plant Sci., 21(3): 626-628.

[18] Ibikunle OA, Omidiji MO and Menkir A (2009). Evaluation and identification of maize hybrids adapted to the southern and northern guinea savannas of Nigeria. African Crop Science Conference Proceedings, 9: 9-15.

[19] Iqbal M, Khan K, Rahman H, Hassan S (2010)a. Detection of epistasis for plant height and leaf area per plant in maize (Zea mays L.) from generation means analysis. Maydica, 55: 33-39.

[20] Iqbal M, Khan K, Rahman H, Khalil IH, Sher H, Bakht J (2010)b. Heterosis for morphological traits in subtropical maize (Zea mays L.). Maydica, 55: 41-48.

[21] International Institute of Tropical Agriculture (1989). Automated and semi-automated methods for soil and plant analysis. Manual series No. 7, IITA, pp. 726, Ibadan, Nigeria.

[22] Kamara AY, Kling JG, Menkir A and Ibikunle O (2003). Agronomic performance of maize (Zea mays L.) breeding lines derived from a low nitrogen maize population. J. Agric. Sci., 141(2), 221-230.

[23] Kamara AY, Friday E, David C and Lucky OO (2009). Planting date and cultivar effects on grain yield in dryland corn production. Agron. J., 101: 91-98.

[24] Khan K, Sher H, Iqbal M and Al-Qurainy F (2011). Development and release of indigenous maize hybrids to enhance 
maize yield in Khyber-Pakhtoonkhua province of Pakistan. Afri. J. Agric. Res., 6(16): 3789- 3792.

[25] Kucharik CJ (2008) Contribution of planting date trends to increased maize yields in the Central United States Agron.100:328-336.

[26] Liu K and Wiatrak P (2011). Corn (Zea mays L.) Plant characteristics and grain yield response to $\mathrm{N}$ fertilization programs in no-tillage system. American J. Agric. Biol. Sci., 6 (2): $279-286$.

[27] Majid K, Zaefizadeh M, Gholamin R and Shahzad JS (2010). Study of genetic diversity and path analysis for yield in durum wheat genotypes under water and dry conditions. J. World App. Sci., 9(6): 655-665.

[28] Naushad A, Turi S, Shah S, Ali S, Rahman H, Ali Tand Sajjad $M$ (2007). Genetic variability for yield parameters in maize (Zea mays L.) genotypes. J. Agric. Bio. Sci., 2(4-5): 1-3.

[29] Nazir H, Zaman Q, Amjad M, and Aziz NA (2010). Response of maize varieties under agro-ecological conditions of Dera Ismail khan. J. Agric. Res., 48(1): 59-63.

[30] Nelson DW and Somers LE (1992). Total carbon, total organic carbon and organic matter. Pp. 539-580. In: Miller, (ed). Methods of soil analysis, Part 2, $2^{\text {nd }}$ Edition, Agronomy Monograph, 27, ASA, Madison, W. I.

[31] Nik MM, Babaeian M, Tavassoli A, and Asgharzade A (2011). Effect of plant density on yield and yield components of corn hybrids (Zea mays L.). Sci. Res. Essays, 6(22): 4821-4825.

[32] Olakojo SA and Olaoye G (2005). Combining ability for grain yield, agronomic traits and Striga lutea tolerance of maize hybrids under artificial Striga infestation. Afr. J. Biotechnol., 4(9): 984-988.

[33] Olaoye G and Omueti HE (2006). Evaluation of short duration maize (Zea mays L.) varieties for adaptation to a typical Southern guinea savanna ecology of Nigeria. J. Agric. Res. Dev., 5 (2): 97-111.

[34] Olaoye G, Menkir A, Ajala SO and Jacob S (2009). Evaluation of local maize (Zea mays L.) varieties from Burkina Faso as source of tolerance to drought. J. Appl. Biosci., 17: 887 898.
[35] Oluwaranti A, Fakorede MAB and Badu-Apraku B (2008). Grain yield of maize varieties of different maturity groups under marginal rainfall conditions. J. Agric. Sci., 53(3):183-191.

[36] Randjelovic V, Prodanovic S, Tomic Z, and Simic A. (2011). Genotype $\mathrm{x}$ year effect on grain yield and nutritive values of maize (Zea mays L.). J. Anim., Vet. Sci. Adv., 10(7): 835-840.

[37] Sallah PYK, Abdullahi MS and Obeng-Antwi K (2004). Genotype by environment interactions in three maturity groups of maize cultivars. Afri. Crop Sci., 12(2): 95-104.

[38] Salami, AE, Adegoke SAO and Adegbite OA, (2007). Genetic variability among maize cultivars grown in Ekiti-State, Nigeria. Middle-East J. Sci. Res., 2(1): 9-13.

[39] SAS Institute, (2007). SAS system for windows version 9.2. SAS Institute. Cary, NC.

[40] Shi ZS, Zhang SH, Li FH, Wang ZP, Zhang XH, Zhang Yl, Zhu M (2008). Comparison and analysis on maize yield performance of mid-maturing, mid-late maturing and late maturing varieties in Liaoning areas. J. Maize Sci., 16(6): 6-10.

[41] Song JM, Li HS, Dai S, Liu AF, Cheng DG, Liu JJ, Zhao ZD (2010). Yield component analysis of Jimai 22 with super high yield potential and wide adaption. J. Nucl. Agric. Sci., 24(6): 1280-1285.

[42] Tahir M, Tanveer A, Ali A, Abbas M and Wasaya A (2008). Comparative yield performance of different maize (Zea mays L.) hybrids under local conditions of Faisalabad-Pakistan. Pak. J. Life Soc. Sci. 6 (2): 118-120.

[43] Wang X, Chang J, Qin G, Zhang S, Cheng X and Li C (2011). Analysis on yield components of elite maize variety Xundan 20 with super high yield potential. Afr. J. Agric. Res., 6(24): 5490-5495.

[44] Yamakawa T, Hee CJI and Jin-Woong CHO (2006). Diallel analysis of plant and ear heights in tropical maize (Zea mays L.). J. Fac. Agr., Kyushu Univ., 51 (2), 233-238. 